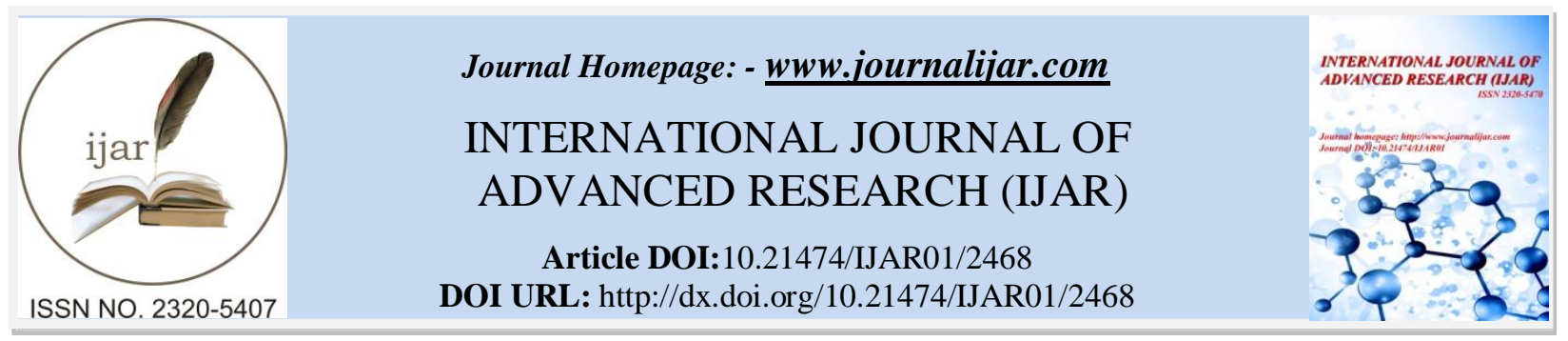

RESEARCH ARTICLE

\title{
ASSESSMENT OF PHYSICO-CHEMICAL PROPERTIES AND ANTI-NUTRITIONAL FACTORS OF FLOUR FROM YAM (DIOSCOREA BULBIFERA) BULBILS IN SOUTHEAST CÔTE D'IVOIRE
}

Jacques Y. Achy, Pamphile K. B. Koffi, Gbocho S. E. Ekissi*, Hubert K. Konan and Lucien P. Kouame. Laboratory of Biochemistry and Food Technology, University Nangui Abrogoua (Abidjan, Cote d'Ivoire), 02 BP 801Abidjan 02, Cote d'Ivoire.

\section{Manuscript Info} .........................

\section{Manuscript History}

Received: 23 October 2016

Final Accepted: 21 November 2016

Published: December 2016

\section{Key words:-}

Anti-nutritional composition, Dioscoreabulbifera, mineral, proximate composition, organic acids.

\section{Abstract}

In oder to increase the value of aerial yam (Dioscoreabulbifera), studies about the physico-chemical properties and anti-nutritional factors on bulbils flour have been investigated. Samples were analyzed for proximate composition, mineral, organic acid content and levels of anti-nutritional factors using standard analytical methods. The moisture content of the bulbils flour were $6.22 \pm 0.87 \% \mathrm{dw}$. The aerial yam (cultivar yellow) had low fat $(2.36 \pm 0.87 \% \mathrm{dw})$, protein $(8.12 \pm 0.02 \% \mathrm{dw})$ ash $(3.44 \pm 0.05 \% \mathrm{dw})$ and cellulose $(0.91 \pm$ $0.08 \% \mathrm{dw})$ but higher levels of carbohydrate $(79.86 \pm 0.09 \% \mathrm{dw})$ and energy $(373.16 \mathrm{kcal} / 100 \mathrm{~g})$. The most predominant mineral were potassium $(847 \mathrm{mg} / 100 \mathrm{~g})$. The major organic acids were oxalic acid $(486 \pm 0.03 \mathrm{mg} / 100 \mathrm{~g})$ and citric acid $(365.4 \pm 0.5 \mathrm{mg} / 100 \mathrm{~g})$. The high anti-nutritional factors (total phenol $558 \pm 3.46 \mathrm{mg} / 100 \mathrm{~g}$, oxalate $320 \pm$ $2.65 \mathrm{mg} / 100 \mathrm{~g}$, phytate $469.33 \pm 2.08 \mathrm{mg} / 100 \mathrm{~g}$ ) could pose a seriousproblem of public health. Therefore, it would be wise to cook bulbils before eating.

Copy Right, IJAR, 2016,. All rights reserved.

\section{Introduction:-}

Roots and their tuber crops such as yams, cassava, cocoyam and sweet potatoes rank next in importance to the cereal grains in providing the major part of the daily caloric needs of people in the tropics (Ihekoronye and Ngoddy, 1985). Yams make a major contribution to the Nutrition of West Africans as a source of carbohydrate, before the introduction of cassava and sweet potatoes. They have been very important in times of famine (FAO, 1991). To fight against hunger and ensure food security of their population, most Africans living in south of Sahara countries have undertaken extensive developpment programs of food plant. Among them, yam is food of choice for millions of people because it represents about $12 \%$ of their basic nutrition (Djèet al., 2010).

The genus Dioscoreacontains a wide range of species used as food (about 600 species) (Coursey, 1967; Degraset al., 1977) although the edible yams are derived from only about ten (FAO ,1991). Despite the diversity of species, only ten have been domesticated. She has given numerous cultivars (Degras, 1986; Hamonet al., 1995).

Yams are the edible tubers of various species of the genus Dioscorea and are important staple foods of many tropical countries including Cộte d'Ivoire, Ghana, Togo, Burkina Faso and Nigeria (Kouakouet al., 2010; Amanzeet al., 2011). It is a major contributor to food security in West Africa (Zannou 2006), but out of the over 600 known yam species (Vernier et al., 1998)., only seven are mostly consumed (Jayakodyet al., 2007). These include DioscorearotundataPoir(White yam), Dioscoreacayenensis(Yellow yam), Dioscoreaalata(Water yam), 
Dioscoreaesculenta(Chinese yam), Dioscoreapraehensalis(Bush yam), Dioscoreadumetorum(Bitter yam)andDioscoreabulbifera(Aerial yam)(Otegbayoet al.,2001; Rely et al., 2006).

Yam in general are eaten boiled or fried or even roasted.TheDioscoreabulbiferais a vigorous climber plant native of West Africa (Hamonet al., 1995). The yam specie produced aerial starchy bulbils. In Côte d'Ivoire, Dioscoreabulbifera comes in two varieties (wild and cultivated), is cultivated for their bulbils which are consumed once cooked like potatoes in water with oil and local ingredients. Aerial yam (Dioscoreabulbifera) is recorded to be an unpopular yam among the edible yam species which unlike the traditional yam produces aerial bulbils that look like potatoes hence the name aerial/air potatoes.

This species of yam is consumed by a small number of communities and is generally underutilized for a number of reasons (Igyoret al., 2004). These include, it having a relatively bitter after-taste compared to other yam species, is unknown to most people, and much work has not been done on it to suggest uses to which it can be put to. However, there is a lot of potential for aerial yam in terms of its nutritional and functional properties that could be taken advantage of to produce diverse industrial products, not to mention its socio-economic importance (Sanful et Engmann, 2016).This bulbils-bearing yam which belongs to the Order Dioscorea, Family Dioscoreaceae, and Genus Dioscoreais unpopular specie among the edible yam species (Nwosu, 2014). Aerial yam is grown for its bulbis and eaten during famine season (Sanfulet al., 2013).

Therefore, investigation into the nutritional and other quality characteristics of the aerial yam is essential, with the ultimate aim being the promotion of its usage, and suggesting plausible products that it could be incorporated into. Since aerial yam has received very low attention by food processors and consumers. This study seeks to investigate the nutrient composition of flour aerial yam (Dioscoreabulbifera) yellow.

The aim of this study was therefore to characterise the flour of aerial yam(Dioscoreabulbifera)bulbils in order to identify appropriate uses it could be put to.

\section{Material and Methods:-}

Raw Materials:-

Bulbils of yam (Dioscoreabulbifera) used for this work were harvested at physiological maturity (6 month after planting) from the forest in Agou (SouthEastof Côte d'Ivoire). They were immediately transported in a heap aired store and stored in which the temperature and the relative humidity rate were $28^{\circ} \mathrm{C} \pm 3{ }^{\circ} \mathrm{C}$ and $82 \pm 5 \%$ respectively.

\section{Production of flour from yam (Dioscoreabulbifera) bulbils:-}

At Six month of maturation just before they start falling due to senescence, bulbils were harvested and weighed. They were then peeled, washed and cut into slices $\left(0.2 \mathrm{~cm}\right.$ thickness). Five hundred of slices were dried at $47^{\circ} \mathrm{C}$ during $72 \mathrm{~h}$. The dried slices were ground and pass through sieve $(250 \mu \mathrm{m}$ size $)$. The obtained flour was kept for analysis.

\section{Proximate analysis:-}

Moisture content (on dry weigh basis) was determined on fresh sliced samples after oven drying at $105^{\circ} \mathrm{C}$ for $24 \mathrm{~h}$ according the procedure of AOAC (1990). Sugars were extracted from flours using $80 \%$ aqueous ethanol. Total sugars were determined using the method of phenol-sulfuric (Dubois et al., 1991). Reducing sugars were determined according to the method of Bernfeld (1955) using DNS. Crude fat was determined exhaustively extracting sample of flours in a soxhlet apparatus using anhydrous hexan as solvent. Cellulose content was determined according to the gravimetric method of Van Soeest (1963). Nitrogen was determined by the Kjeldahl method reported by AOAC (1990) and crude protein content was subsequently calculated by multiplying the nitrogen content by a factor of 6.25. Starch content was esteemed by using the polarimetric method of BIPEA (1976). Ash content was determined by measurement of residues left after combustion in a furnace at $550^{\circ} \mathrm{C}$ for $8 \mathrm{~h}$ (AOAC, 1990). The organic matters were determined by the difference between the value of dry matter and total ash. Energy were obtained by the summation of multiplied mean values for protein, fat and carbohydrate by their respective Atwater factors, 4, 9 and 4 (Udosen, 1995). 


\section{Determination of total carbohydrate:-}

Total carbohydrate was calculated by the difference between 100 and the sum of moisture, ash, crude fat, crude protein and crude fibre (Kirk and Sawyer, 1981): \% CHO = $100-(\%$ moisture+ \%protein \% ash + \%fat content+ \% Crude fiber).

\section{Mineral analysis:-}

Minerals were analyzed by the method reported by Oshodi (1992). The ash obtained from 1g of sample was dissolved in $10 \% \mathrm{HCl}$, filtered with filter paper and made up to standard volume with dionised water. Flame photometry method reported by AOAC (1990) was used to determine sodium and potassium contents of the sample. Calcium, Fe, Mg were determined using Atomic Absorption Spectrophotometer (AAS). The total phosphorus was estimated colorimetrically (UV-visible spectrophotometer, Model DR 2800/United States) (Tausky et Shorr, 1953).

\section{Organic acids analysis:-}

Liquid Chromatography High Performance (HPLC) was performed according to method of Ho et al. (1990). Fifty (50) $\mathrm{mg}$ of flour was dissolved in $75 \mathrm{ml}$ of distilled water. The mixture was homogenized manually for $2 \mathrm{~min}$ and centrifuged at $4000 \mathrm{rpm} / \mathrm{min}$ for $30 \mathrm{~min}$ at $4^{\circ} \mathrm{C}$ in a centrifuge (Sigma Aldrich 2-PK). Supernatant obtained, was filtered on WATTMAN paper $\mathrm{n}^{\circ} 4$ and then through millipore filter $0.45 \mu \mathrm{m}$. $20 \mu$ l of each solution obtained were analysed by an HPLC system (Schimadzu Corporation, Japon) equiped with a binary pum coupled to a UU-VS (SPD-6A) detector. Chromatographic separation of organics acids was perfomed on a column ISSep ICE ORH-801 at temperature set at $35^{\circ} \mathrm{C}$. The flow rate of elution was $0.5 \mathrm{ml} / \mathrm{min}$. The chromatogramm obtained at $280 \mathrm{~nm}$ were compared to those standard of organics acids

\section{Total phenolic compounds analysis:-}

Total phenolic compounds were determined according to method of Julkunen-Titto (1985) using Folin-ciocalteu. A volume of $0.1 ; 0.2$ or $0.3 \mathrm{ml}$ of phenolic extract was diluted in $0.9 ; 0.8$ or $0.7 \mathrm{ml}$ of distilled water contained in the test tube. Consequently $0.5 \mathrm{ml}$ of Folin-cioclteu was added to this solution. The mixture was homogenized by manual stirring at room temperature $\left(28^{\circ} \mathrm{C}\right)$, then leave rested on bench for $3 \mathrm{~min}$. A volume of $2.5 \mathrm{ml}$ of an aqueous solution of sodium $(2 \%, \mathrm{p} / \mathrm{v})$ was added thereto after this reaction time. The new mixture was homogenized by manual stirring for 2 minutes and incubated on bench for 2 hours. The color intensity of the mixture was determined in a spectrophotometer at $760 \mathrm{~nm}$ against a controle which has not containing phenolic extrait. The optical density were converted to $\mathrm{mg}$ of phenolic compound thanks to a calibration line prepared in the same conditions as the test and was used as the gallic acid standard phenolic compound.

\section{Anti-Nutritional factors analysis:- Tannin analysis:-}

Total tannin content of yam Dioscoreabulbifera was determined by the spectrophotometric procedure described by Brainbridgeet al. (1996).

\section{Phytate analysis:-}

The phytate was extracted with trichloacetic acid (TCA) and precipitated as ferric salt using the procedure outlined by Weeler and Ferrel (1979).

\section{Total oxalates analysis:-}

The level of total oxalates was detemined by titration to warm of an aliquot acidified flour extract with a solution of sodium permaganate according to AOAC (1970). $0.75 \mathrm{~g}$ of flour was introduced into $100 \mathrm{ml}$ of flash containing 76 $\mathrm{ml}$ of distilled watter and $4 \mathrm{ml}$ of hydrochloric acid. The mixture was homogenized by manual stirring for 2 min and then heated to boiling water bath for 1 hour. It was then cooled in an ice bath for $30 \mathrm{~min}$ and the volume was ajusted to the mark with distilled water. After filtration, first two aliquot of $40 \mathrm{ml}$ each, were introduced separately in two beaker which had each receved $20 \mathrm{ml}$ of hydrochloric acid. The mixture was evapored to half volume from the original and filtered on filter paper. The precipity retained on the filter paper was washed several times with hot water until a volume about $60 \mathrm{ml}$ was obtained. The resultant filtrate scored 3 trops of methyl red and ammonia until obtained pale yellow coloration. The solution was heated to boiling in a water bath for $20 \mathrm{~min}$. It was cooled in an ice box for $10 \mathrm{~min}$, then filtered to removed the precipitate of ferrous ion. The filtrate obtained was boiled for 10 min, then $5 \mathrm{ml}$ of calcium chloride were added to it with constant stirring and let stand overnight. It was filtered on filter paper and calcium oxalate $(5 \%, \mathrm{p} / \mathrm{v})$ precipitate retaned by the filter paper was transfered to a beaker with distilled water and sulfuric acid until to obtain complete dissolution to precipitate heavy metals, $5 \mathrm{ml}$ of 
tungstophosphonate reagent were added to the acidified extract and the mixture was centrifuged at $5000 \mathrm{rpm} / \mathrm{min}$ for 15 min. The supernatant was titrated hot with constant stirring with solution of potassium permaganate.

\section{Inhibitor of alpha-amylase activity:-}

Anti-alpha amylase activity was determined according to method described by Lonstaff and Mc Nab (1991). $1 \mathrm{~g}$ of flour was dissolved in $10 \mathrm{ml}$ of $100 \mathrm{mM}$ acetate buffer. The mixture was homogenized and allowed to stand at $4^{\circ} \mathrm{C}$ for 12 hours and then centrifuged at $5000 \mathrm{rpm} / \mathrm{min}$ for $20 \mathrm{~min}$. A volume of $0.25 \mathrm{ml}$ of this extract was preincubated with $0.25 \mathrm{ml}$ of a solution of alpha-amylase and $0.25 \mathrm{ml}$ of $100 \mathrm{mM}$ acetate for $15 \mathrm{~min}$ in buffer from $35^{\circ} \mathrm{C}$. A volume of $0.5 \mathrm{ml}$ of starch $(1 \%, \mathrm{p} / \mathrm{v})$ was added. After $30 \mathrm{~min}$ of incubation, the reaction was screeching halt by adding $2 \mathrm{ml}$ of dinitosalicylic acid (DNS) and heated in a bath-marie boiling for $5 \mathrm{~min}$. The tuber was allowed to cool on the bench for $10 \mathrm{~min}$, then $3 \mathrm{ml}$ of water were added thereto. Staining intensity was determined in a spectrophotometer at $540 \mathrm{~nm}$ against a withness which was not contained happy enzyme extract.

\section{Inhibitor of trypsin activity:-}

Anti-trypsin activity was determined by the method described by Alonso et al. (1998). For extracting the inhibitor, 1 $\mathrm{g}$ of flour was dissolved in $10 \mathrm{ml}$ of phospte buffer at $4^{\circ} \mathrm{C}$. The solution obtained was homogenized by manual stirring for $2 \mathrm{~min}$ and then left to stand overnight with mechanical stirring at $4^{\circ} \mathrm{C}$. It was then centrifuged at 5000 $\mathrm{rpm} / \mathrm{min}$ for the extract tobeanalysed. Avolume of $20 \mu \mathrm{l}$ of the extract was pre-incubated with $250 \mu \mathrm{l}$ of trypsin solution $(0.04 \mathrm{~g} / \mathrm{kg}$ of trypsin in $0.025 \mathrm{M}$ glycine-Hcl buffer) and $1 \mathrm{ml}$ of $0.15 \mathrm{M}$ of phosphate buffer (pH 8.1) for 15 min at room temperature $\left(28^{\circ} \mathrm{C}\right)$. Then a volume of $2.5 \mathrm{ml}$ of benzyl-DL-Arginine p-nitroanilide hydrochloride $(0.001 \mathrm{M})$ prepared in phosphate buffer $(\mathrm{pH} 8.1)$ was added quickly. After $30 \mathrm{~min}$ of incubation, the intensity of staining was determined in a spestro photometer at $410 \mathrm{~nm}$ against a control containing no enzyme extract.

\section{Statistical analysis:-}

All analyses reported in this study were carried out in triplicate. Statistical significance was established using Analysis of Variance (ANOVA) models. Mean comparison was carried out using Duncan's multiple range test ( $\mathrm{p}<$ 0.05), with the help of the software STATISCA 7.1 (StatSoftInc, Tulsa USA Headquarters).

\section{Results and Discussion:-}

\section{Proximate analysis:-}

The proximate composition of flour from yam (Dioscoreabulbifera) bulbils are shown in Table 1. Moisture content estimates directly the water content and indirectly the dry matter content of the sample. It is also an index of storage stability of the flour. Flour with moisture content less than $14 \%$ can resist microbial growth and thus has better storability (Colas, 1998 ; Okonkwo and Opara. 2010). The moisture content obtained in this study (6.22 \pm $0.11 \%$ ) was lower than those found byOgbuagu, (2008) and Abara, (2011) (7.029\% and 9.20\% respectively). This slight difference could be associated to the level of maturity, environmental factors, experimental method of analysis, level of maturity of the tuber and type of cultivar used (Coursey, 1983 ;Abaraet al., 2003).

Table 1:- Proximate composition of flour from yam (Dioscoreabulbifera) bulbils.

\begin{tabular}{|c|c|}
\hline Parameters & Composition (\%) \\
\hline Moisture & $6.22 \pm 0.11$ \\
\hline Ash & $3.44 \pm 0.05$ \\
\hline Protein & $8.12 \pm 0.02$ \\
\hline Fat & $2.36 \pm 0.02$ \\
\hline Cellulose & $0.91 \pm 0.03$ \\
\hline Total carbohydrates & $79.86 \pm 0.09$ \\
\hline Starch & $70.49 \pm 0.05$ \\
\hline Reducing sugars & $0.48 \pm 0.03$ \\
\hline Total sugars & $3.26 \pm 0.04$ \\
\hline Oganic acids & $90.34 \pm 0.06$ \\
\hline Energy (Kcal) & $373.16 \pm 0.11$ \\
\hline
\end{tabular}

The ash content of the yellow cultivar were found to be higher when compared with earlier report of Abaraet al., (2003) who reported an ash content of 2.24\%. Ash content of bulbils of yam (Dioscoreabulbifera) (3.44 $\pm 0.05 \%)$ is lower than that obtained in bètè-bètè (Dioscorealata) yam tubers which is $4.64 \pm 1.83 \%$ (Assaet al., 2014). The 
percentage of ash obtained in this study shows that D.bulbifera will be rich in minerals. Ash content is a reflection of the mineral status, even though contamination can indicate a high concentration in a sample.

The protein content of flour from of yam (Dioscoreabulbifera) bulbils $(8.12 \pm 0.02 \%)$ is similar to that reported by Sahore and Amani (2013) but high in flours of the same specie (Libra et al., 2011).It appeared that protein content of flour from aerial yam (D. bulbifera) was higher than that reported on bananas (1.09\%) (Mahapatraet al., 2012); white yam (5.15\%) and sweet potato (3.64\%) (Alaise and Linden, 1999) Thus, incorporating aerial yam flour in diet could contribute in amino acid balance.

Flour from yam (Dioscoreabulbifera) bulbils have low cellulose content which is $0.91 \pm 0.03 \%$. That level is similar to that obtained in flour Dioscoreabulbifera purple cultivar after six months traning (Libra et al., 2011).

The fat content $(2.36 \pm 0.02 \%)$ of flour from yam bulbils was quite reasonable as all root crops contain very low fat content (Ekpeyong, 1984). Thisfat content was comparably higher than that of white yam (Dioscorearotundata), $0.56 \%$ and sweet potato, $0.95 \%$ (Alaise and Linden,1999)butis lower than that obtained of flour of green cultivar of Dioscoreabulbifera which is $4.15 \%$ (Princewill-Ogbonna and Ibeji, 2015). However, yams generally contain low levels of fat (Oyenuga, 1959; Shanthakumariet al., 2008).

The organics matter content of bulbils $(93.34 \pm 0.06 \%)$ is close to that obtained in flour of kponan (Dioscoreacayenensis-rotundata) which is $91.23 \pm 0.4 \%$ (Konéet al., 2014).

The starch is the most important chemical component in the flours. Apart from its energy contribution, starch in most of the processed food systems is known to contribute to the texture, and as a result, to the organoleptic properties of food (Tharanathan and Mahadevamma, 2003). Flour from yam (Dioscoreabulbifera) bulbils have high starch content $(70.49 \pm 0.05 \%)$ which. are lower than that repoted by Assaet al. (2014) in flour of bètè-bètè (Dioscoreaalata) yam tubers $(74.87 \pm 1.18 \%)$.

The total and reducing sugar contents in flour from yam bulbils are respectively $0.48 \pm 0.03 \%$ and $3.26 \pm 0.4 \%$. This is in accordance with the observation of Sahoré and Amani (2005) on of Dioscoreaalata tubers.

Flourfromyam (Dioscoreabulbifera) bulbils have high carbohydrates level $(78.86 \pm 0.09 \%)$. High rate of carbohydrates shown that bulbils are energy food, that can contribute to food security in developing countries (FAO, 2001).These values are comparable to literature values 76.80 - 78.3\% (Bell and Favier, 1981; Eka, 1985) and 81.31 - 87.64\% (Udensiet al., 2008). The high carbohydrate and energy values of the flour yam recorded in this study make them reliable food security crops. The carbohydrate content of flour from aerial yam (76.570\%) agrees with the work of Onyenuga (1968), which reported that the dry matter of most root and tuber crops is made up of about 60 to $90 \%$ carbohydrate.

Flour of yam (Dioscoreabulbifera) bulbils have high energy value level (373.16 $\pm 0.11 \mathrm{kcal} / 100 \mathrm{~g})$. With this energy value, the flour of yam (Dioscoreabulbifera) could be used as energy in the flour poridge for infants and children (Butte, 1996).

\section{Mineral analysis:-}

Table 2 showns mineral content of flour of yam (Dioscoreabulbifera) bulbils.

Table 2:- Mineral content of flour from yam (Dioscoreabulbifera) bulbils.

\begin{tabular}{|c|c|}
\hline Parameters & Composition $(\mathrm{mg} / 100 \mathrm{~g} \mathrm{MS})$ \\
\hline $\mathrm{P}$ & $37.8 \pm 1.21$ \\
\hline $\mathrm{Na}$ & $48.1 \pm 2.29$ \\
\hline $\mathrm{Ca}$ & $77.1 \pm 1.97$ \\
\hline $\mathrm{Fe}$ & $7.14 \pm 0.03$ \\
\hline $\mathrm{K}$ & $847 \pm 1$ \\
\hline $\mathrm{Mg}$ & $86.5 \pm 1.32$ \\
\hline $\mathrm{K} / \mathrm{Na}$ & $17.63 \pm 0.85$ \\
\hline $\mathrm{Ca} / \mathrm{P}$ & $2.03 \pm 0.09$ \\
\hline
\end{tabular}


The phosphoruscontent of flour from yam (Dioscoreabulbifera) bulbils $(37.8 \pm 1.21 \mathrm{mg} / 100 \mathrm{~g}$ of dry matter) is lower than that obtained in D. bulbiferawhich is $65.98 \pm 0.55 \mathrm{mg} / 100 \mathrm{~g}$ of dry matter) (Libra et al., 2011). The phosphorus content of the flour is an indication that the flour products will help in the formation of teeth and bones in children and their proper development.

Sodium level of flour of yam (Dioscoreabulbifera) bulbils is $48.1 \pm 6.55 \mathrm{mg} / 100 \mathrm{~g}$ of dry matter). The daily sodium intake of an adult is $500 \mathrm{mg}$ (NRC, 1989). With this low level in sodium, flour could be used as food without health risk for people with blood pressure.

Calcium level of flour from yam (Dioscoreabulbifera) bubils $(77.1 \pm 1.97 \mathrm{mg} / 100 \mathrm{~g}$ of dry matter) is higher than that reported in plantain banana which is $7 \mathrm{mg} / 100 \mathrm{~g}$ of dry matter (FAO, 1999; Gayelord, 2000;Boukariet al., 2001). The calcium is necessary for blood clotting. Its regulates the acid-basic balance of blood, thus preventing the latter to be acids (Garcia-chuit and Boella, 2000).

The iron is the lowest mineral of flour from aerial yam (Dioscoreabulbifera). It level is $7.14 \pm 0.03 \mathrm{mg} / 100 \mathrm{~g}$ of dry matter. Iron plays an important role in children development (Kordas and Stoolzfus, 2004).

The potassium the highest mineral of flour from yam (Dioscoreabulbifera) bubils. Its level is $847 \pm 1 \mathrm{mg} / 100 \mathrm{~g}$ of dry matter. Potassium regulates the heartbeat and blood pressure, the water content of the body and neuromuscular excitability.

Magnesium rate of flour from yam (Dioscoreabulbifera) bubils is low (v86.5 $\pm 1.32 \mathrm{mg} / 100 \mathrm{~g} \mathrm{dw}$ ). Like magnesium rate relatively low, the flour would be used in a regimen to improve calcium absorption because magnesium is essential for calcium metabolism (Seeling, 1993; Kenney et al, 1994).

The K/Na ratio (17.60) was close to the recommended 5.0 (Szentmihalyiet al., 1998). Dietary changes leading to reduce consumption of potassium than sodium have health implications. Diets with higher ratio $\mathrm{K} / \mathrm{Na}$ are recommended and these are found usually in whole foods (Arbeitet al., 1992). Foods, naturally higher in potassium than sodium, may have a K/Na ratio of 4.0 or more (CIHFI, 2008).

The $\mathrm{Ca} / \mathrm{P}$ ratio of flour of yam (Dioscoreabulbifera) bubils is $2.03 \pm 0.09$. Food must have $\mathrm{Ca} / \mathrm{P}$ of 1 or more. High consumption of flour of yam (Dioscoreabulbifera) bubils could be recommanded in diet to prevent osmotic and mineral imbalance in some sick (Appiahet al., 2011).

\section{Organic acid analysis:-}

The organic acid content of yam (Dioscoreabulbifera) bulbils is resumed in table 3.Citric acid is the highest organic acid and sulfanilic acid the lowest of flour from yam (Dioscoreabulbifera) bubils. Their rate are respectively $365.4 \pm$ $0.5 \mathrm{mg} / 100 \mathrm{~g}$ of dry matter and $1.78 \pm 0.02 \mathrm{mg} / 100 \mathrm{~g}$ of dry matter. Organic acids play an important role in food because they prevent the proliferation of microorganism (Smulder and Greer, 1998).

Table 3:- Organic acids composition of flour from yam (Dioscoreabulbifera) bulbils

\begin{tabular}{|c|c|}
\hline Parameters & Composition $(\mathrm{mg} / 100 \mathrm{~g})$ \\
\hline Citric acid & $365.4 \pm 0.5$ \\
\hline Tannic acid & $4.08 \pm 0.02$ \\
\hline Oxalic acid & $486 \pm 0.03$ \\
\hline Sulfanic acid & $1.78 \pm 0.02$ \\
\hline Tartaric acid & $3.26 \pm 0.01$ \\
\hline
\end{tabular}

\section{Anti-nutritionnal factors analysis:-}

Anti-nutritionnal factors content are resumed in table 5. The determination of the anti-nutritional substances was of interest because of their toxicity in yams, negative effects on mineral bioavailability and their pharmacological effect. The anti-nutritionals factors are substances of reserves of plants which complex some nutrients like rock salt, proteins and reduce their biodisponibility during digestion. It is the case of oxalates, the phytate, tannins and total phenols, etc. These results of content of anti-nutritional factors were higher than those reported by other authors on the yam tubers. 
Table 4:- Anti-nutritionnal factors composition of flour from yam (Dioscoreabulbifera) bulbils

\begin{tabular}{|c|c|}
\hline Parameters & Composition $(\mathrm{mg} / 100 \mathrm{~g})$ \\
\hline Total phenol & $558 \pm 3.46$ \\
\hline Total oxalate & $320 \pm 2.65$ \\
\hline Phytate & $469.33 \pm 2.08$ \\
\hline Tannins & $66 \pm 1.73$ \\
\hline$\alpha$-amylase inhibitors & $251 \pm 2.65$ \\
\hline Trypsin inhibitors & $197 \pm 1.73$ \\
\hline
\end{tabular}

Phenol content of $558 \pm 3.46 \mathrm{mg} / 100 \mathrm{~g} \mathrm{dw}$ was identified in flour from aerial yam (D. bulbifera). The presence of phenols indicates that Dioscorea species could act as anti-inflammatory, anti clotting, antioxidant, immune enhancers and hormone modulators (Okwu and Omodamiro, 2005).

Tannin content of flour from yam (Dioscoreabulbifera) bulbils is $66 \mathrm{mg} / 100 \mathrm{~g}$ of dry matter was lower than those in wild yam tubers (Dioscoreaspecies )(Sahoréet al., 2006). The comsumption of food rich in tannin can cause oesophageal cancer (Shilset al.,2006). Tannins have been reported to form complexes with proteins and reduce their digestibility and palatability (Eka, 1985). However, their contents in foods are known to reduce through cooking (Lewuet al., 2010). Tannin affects the nutritive value of food products by forming complex with protein (both substrate and enzyme) thereby inhibiting digestion and absorption (Osuntogunet al., 1989). They also bind iron, making it unavailable (Aletor and Adeogun, 1995). The phenolics and tannins are water soluble compounds (Uzogaraet al., 1990) and as such can be eliminated by soaking followed by cooking (Singh, 1988; Katariaet al., 1989; Murugesan and Ananthalakshmi, 1991; Singh and Singh, 1992; Shanthakumariet al., 2008).

Total oxalate content of yam (Dioscoreabulbifera) bulbils is $320 \pm 2.65 \mathrm{mg} / 100$ of dry matter. The lethal oxalate content in food is between 2 and $5 \mathrm{~g}$ (Oké, 1966). With this low lever, bulbils consumption would be safe humans.

Phytate content of yam (Dioscoreabulbifera) bulbils is $469.33 \pm 2.08 \mathrm{mg} / 100$ of dry matter. Knowledge of phytate levels in food is necessary because a high content can cause HARMFUL effects on digestibility (Nwokolo and Bragg, 1977). Phytate has been recognized as an anti-nutrient due to its adverse effects. It reduced the bioavailability of minerals and caused growth inhibition. Thephytate contents of bulbils yams were higher, with values ranging from $0.89 \mathrm{mg} / 100 \mathrm{~g}$ in D. alata(Akaba) to $4.16 \mathrm{mg} / 100 \mathrm{~g}$ dry matter in D. cayenensis (Pure yellow flesh), compared to the $58.6-198 \mathrm{mg} / 100 \mathrm{~g}$ on cultivars of $D$. alatareported by Wanasundera and Ravindran (1994). This phytate content of flour yam bulbils ranging from those of 400 to $2060 \mathrm{mg} / 100 \mathrm{~g}$ reported for cereals and grain legumes (Reddy et al., 1982).

Phytates and oxalates are known to adversely affect mineral bioavailability (Bhandari and Kawabata, 2006).

$\alpha$-amylase inhibitors content of yam (Dioscoreabulbifera) bulbils is $251 \mathrm{AUI} / \mathrm{g}$ of dry matter. Inhibitors delay the $\alpha$ amylase hydrolysis of starch and thus reduce glucose uptake (Nickavaret al., 2008).

Trypsin inhibitors content of yam (Dioscoreabulbifera) bulbils is $197 \mathrm{TUI} / \mathrm{g}$ of dry matter. The inhibitors are protein which are able to inhibe serine proteases such as trypsin and chymotrypsin. Their act in formation of enzyme-trypsin are irreversible and this result cause hypertrophy of pancreas and hypersecretion of pancreatic enzymes (Besançon, 1994).

The values are very high compared to those ranged from 46.50 \pm 0.29 - $180 \pm 0.0033$ obtained for Mucunacochinchinensis(7.47 TI unit/mg) mg/100g and Mucunautilis(13.00 TI unit/mg) by Ukachukwu and Obioha (1997) and Udensiet al.,(2004), respectively. The presence of large quantity of trypsin inhibitor in the body disrupts the digestive process and may lead to complex formation. However, it is important to note that undesirable physiological reactions (Booth et al.,1960).

\section{Conclusion:-}

The study was carried to enhance the flour from yam (Dioscoreabulbifera) bulbils. The physico-chemical characterization of its flour shows their high dry matter, organic matter, total carbohydrates, energy value and potassium hence their interest in the use of humain diet. The low moisture content which makes them store for a 
long time.However, their high anti-nutritional factors (phenol, phytates, total oxalates, tannins, $\alpha$-amylase and trypsin inhibitors) can pose a seriousproblem of public health. Therefore, it would be wise to cook bulbils before eating.

\section{References:-}

1. Abara,A. E Udosen, E. O and Eka, O. U. (2003): Moisture Content and Poly phenol Oxidase activity of growing (Dioscoreabulbifera) as indicators of tuber maturation, global J. pure Applied Sci., 9: 113-115.

2. Abara, A. E. (2011): Proximate and Mineral Elements Compositions of the tissue and peel of Dioscoreabulbifera tuber. Pakistan. Journal of nutrition $10: 543-551$

3. AlaiseC.and Linden G. (1997) :Abrégé de biochimiealimentaire. Edition Masson. Paris, 248.p.

4. Aletor, V.A and Adeogun, O.A (1995): Nutrient and antinutrient components of some tropical leafy vegetables. Food Chem. 53:375-379.

5. Alonso, R., Orue, E., andMarzo, F. (1998): Effet of extrusion and conventional processing methods on protein and antinutrional factor contents in pea seeds. Food Chem 63: 505-512.

6. Amanze, N.J., Agbo, N.J., Eke-Okoro, O.N. and Njoku, D.N. (2011): Selection of yam seeds from open pollination for adoption in yam (DioscorearotundataPoir) production zones in Nigeria. Journal of Plant Breeding and Crop Science 3 (4): 68-73.

7. AOAC. (1970): Association of Official Analytical Chemistry of Analysis. II Edition. W. Horwitz. Ed.; Washington, U.S.A. pp. 236.

8. AOAC. (1990): Official Methods of Analysis. $15^{\text {th }}$ Edn. Association official Analytical Chemists. Washington D.C.

9. Appiah, F., Oduro, I.and Ellis, W.O. (2011): Proximate and mineral composition of Artocarpusaltilis pulp flour as affected by fermentation. Pakistan Journal of Nutrition 10: 653-657.

10. Arbeit, M.L., Nicklas, T.A. and Berenson, G.S. (1992): Considerations of dietary sodium/potassium/energy ratios of selected foods. J. Am. Coll. Nutr., 11: 210-222.

11. Assa, C.D., Konan, K.H., Djè, K.M.andKouamé, P.L. (2014):Effect of boiling time on some biochemical parameters of yam specie (Dioscoreaalata variety bètè-bètè) tubers. International Journal of Advanced Research 2 (11): 40-50.

12. B.I.P.E.A. (1976): Bureau Interprofessionneld'EtudesAnalytiques, recueil des méthodesd'analyse de la communautéEuropéenne, 110 p.

13. Bell, A. and Favier, J.C. (1981): Effect of traditional food processing methods on the nutritional value of yam in Cameroon. IDRC: tropical root crops: Proc 1 Trienn Root Crops Symp Ibadan. 163: 214-224.

14. Bernfeld, P. (1955): Alpha and beta- amylases. In: Methods in Enzymology, Colowick. S.P. and Kaplan N., eds. Academic Press. New York 1: 149-158.

15. Besançon, P. (1995): Innocuité et disponibilité des nutriments dans les aliments de complements In : TRECHE S. et col.. L'alimentation de complément du jeune enfant. Paris : ORSTOM, (Collection Colloques et Séminaires): 105-122

16. Bhandari, M.J. and Kawabata, J. (2004): Organic acid, phenolic content and antioxidant activity of wild yam (Dioscoreaspp.) tubers of Nepal. Food Chemistry 88: 163-168.

17. Booth, A.N., Robbins, D.J.andRibelin, W.F. (1960): Effect of soybean meal and amino acids on pancreatic hypertrophy in rats. Pro. Soc. Exp. Bio. Med., 104: 68-72.

18. Boukari, I., Shier, N.W., Fernandez, X.E., Frisch, J., Watkins, B.A., Pawloski, L and Flya, D. (2001):Calciumanalys of selected. Westen African Food. Journal of Food comp and anal 14: 37 - 42.

19. Butte, N.F. (1996): Energy requirements of infants. European Journal of Clinical Nutrition 50: 24-36.

20. CIHFI. (2008): Potassium/sodium ratio (K/Na ratio). The Center for the improvement of human functioning international. http://biocenterlab. org/tests/urine/kna.shtml. Accessed on August 14, 2010.

21. Colas, A. (1998): Définition de la qualité des farines pour les différentesutilisations. In, Godon B., Will M C. Les industries de première transformation des céréales. Lavoisier. Tec et Doc/Apria. Paris 679 p.

22. Coursey, D.G. (1967): Yams. An accont of the nature, and utilization of the useful member of the Dioscorea. Tropical agriculture sents, tropical products Institue.

23. Coursey, D. G. (1983): Yams. In: Handbook of Tropical foods (Chan, H.V., Ed.) Marcel Dekker, Inc. New York and Basel, pp: 555-601.

24. Degras, L. (1986): L'igname, technique agricoleet production tropicale. Ed. G-P.Maisonneuveet Larousse, Agenda de coopérationculturelle et technique, $409 \mathrm{p}$.

25. Degras, L., Arnolin, R., Portout, A. and Suart, C. (1977): Quelques aspects de la bioloigie des ignames (Dioscoreaspp). I. Les ignamesetleurs cultures. Annales de l'amélioration des plantes 27: 1-23. 
26. Djè, K.M., Dabonné, S., GuehiTagro, S. and Kouamé, L.P. (2010):Monitoring of some Biochemical Parameters of two yam species (Dioscoreaspp) Tubers Parts during Post-Harvest Storage. Advance Journal of Food Science and Technology, 2 (3): 178-183.

27. Dubois, M.K.A. Gilles, J.K. Hamilton, P.A. Rebers, P.C. Edison and. Figueiredo-Ribeiro R.C.L (1991): Native and exotic species of Dioscoreaused as food in Brazil. Econ. Bot., 45(4): 487-479.

28. Eka, O.U. (1985): The Chemical Composition of Yam Tubers In: Advances in Yam Research. The Biochemistry and Technology of Yam Tubers. Osuji, G. (ed.). Biochemical Society of Nigeria Enugu, Nigeria. $1: 51-75$.

29. Ekpeyong, T.E (1984): Composition of some Tropical Tuberous Foods. Food Chem. 15:31-36.

30. FAO (2001): Food and Agriculture organization of the United Nations: Production 1995, vol.50.Rome, Italy.

31. FAO. (1991): Post-Harvest And Processing Chorologist of African Staple Foods pp. 225-235.

32. FAO. (1999): Food and Agriculture Organization of the United Nations. Production Yearbook vol 53. FAO Statistics 1999. FAO, Rome, Italy.

33. Garcia-Chuit, C.F and Boella, C. (1993): Minerals why. how... how many... Ed Nestec S.A p. 5-18.

34. Gayelord, H. (2000): Dietetics a new health hunger. Collection «Know everything». Edition Paris, pp. 51-64.

35. Hamon, P. Dumont, R. Zoundjihekpon, J. tio-Toure B. and Hamon, S. (1995): Wild yams of West Africa. HMorphological characteristics. Ed. de l'Orstom, Paris, pp: 385-400.

36. Ho, P., Hogg, T.A and Silva, M.C.M. (1999): Application of a liquid chromatography for the determination of phenolic compounds and furans in fortified wines. Food Chemistry 64: 115-122.

37. Igyor, M. A., Ikyo, S. M., and Gernah, D. I. (2004): The food potential of potato yam (DioscoreaBulbifera). Nigerian FoodJournal; 22: 209-215.

38. Ihekoronye, A. I. and Ngoddy, P. O. (1985): Integrated Food Science and Technology for the Tropics Macmillan Publishers ltd., London and Basin Sloke, pp: 266-282.

39. Jayakody, L., Hoover, R., Liu, Q. and Donner, E. (2007): Studies on tuber starches. II. Molecular structure, composition and physicochemical properties of yam (Dioscoreasp.) starches grown in Sri Lanka. Carbohydrate Polymers 69: 148-163.

40. Julkunen-Titto, R. (1985): Phenolic Constituents in the Leaves of Northern Willows: Methods for the analysis of Certain Phenolics. Journal of Agricultural and Food Chemistry. 33: 213-217.

41. Kataria, A., Chauhan, B.M.andPunia, D (1989):Antinutrients and protein digestibility (in vitro) of mungbean as affected by domestic processing and cooking, Food Chemistry, 32: 9-17.

42. Kenney, M.A., McCoy, H. and Williams, L. (1994): Effects of magnesium deficiency on strength, mass and composition of rat femur. Calcif Tissue Int., 54: 44-49.

43. Koné, D., Koné, M.F., Djè, K.M., Dabonné, S.andKouamé, P.L (2014): Effect of cooking time on biochimical and fonctional properties of flours from yam "kponan" (Dioscoreacayenensis-rotundata) British Journal of Applied Science \&Technology 4 (23): 3402-3418.

44. Kordas, K.andStoltzfus, R.J. (2004): New evidence of Iron and Zinc interplay at the enterocyte and neural tissues. Journal of Nutrition 134: 1295-1298.

45. Kouakou, M.D., Dabonne, S., Guehi, T. and Kouame, L.P. (2010): Effects of post-harvest storage on some biochemical parameters of different parts of two yams species (Dioscoreaspp). African Journal of Food Science and Technology 1 : 1-9.

46. Lewu, M.N., Adebola, P.O. and Afolayan, A.J. (2010): Effect of cooking on the mineral contents and antinutritional factors in seven accessions of Colocasiaesculenta (L.) Schott growing in South Africa. Journal of Food Composition and Analysis 23: 389-393.

47. Libra, M.A., Gonnety, J.T., Ahi., A.P., Dabonné, S., Ahipo, E.D.andKouamé L.P. (2011): Physicochemical changes in bulbils of two cultivars of Dioscoreabulbifera during the ripening period. Journal of Food Science and Technology 3 (5): 327-331.

48. Lonstaff, M.A and Mc Nab, J.M. (1991): The effect of concentration of tannin-rich bean hulls (ViciafabaL.) on activities of lipase (EC 3.1.1.3) and alpha-amylase (EC 3.2.1.1) in digesta and pancreas on the digestion of lipid and starch by young chicks. British Journal of Nutrition 66: 139-147

49. Mahapatra, A.K., Mishra, S., Basak, U.C. and. Panda, P.C. (2012): Nutrient Analysis of Some Selected Wild Edible Fruits of Deciduous Forests of India: an Explorative Study towadsNon Conventional Bio-Nutrition. Adv. J. Food Sci. Tech., 4: 15-21.

50. Médoua, N.G. (2005): Etude du durcissement post-récolteet des conditions de transformation des tubrculesdurcis en farine. Potentielnutitionnelettechnologique des tuberculesdurcis de l'ignameDioscoreadumetorum (kunth) paxDoctorat de Thèse/PhD. 254 p. 
51. Murugesan, P.T, and Ananthalakshmi, A. (1991): Dietary practices of the Palliyartribal group and the nutrient content of unconventional foods consumed. Indian Journal of Nutrition and Dietetis. 28:297-301.

52. Nickavar, B., Abolhasani, L.andIzadpanah, H. (2008): $\alpha$-Amylase Inhibitory Activities of Six Salvia Species. Iranian Journal of PharmaceuticalResearch 7: 297-303.

53. NRC/NAS (1989): National Research Council Committee on Dietary Allowances. Recommended Dietary Allowances. 10th edn.National Academy of Science Press, Washington DC, USA.

54. Nwokolo, E.N.and Bragg, B.B. (1977): Influence of phytic acid and crude fiber on the availability of minerals from protein supplements in growing chicks. Journal of Animal Science 57: 475-477.

55. Nwosu, J.N (2014): Evaluation of the proximate and sensory properties of biscuits produced from aerial yam flour (Dioscoreabulbifera).2(3) :120-126.

56. Ogbuagu, M.N. (2008):Nutritive and anti-nutritive composotion of the will (in-edible) species of Dioscoreabulbifera (potato yam) and Dioscoreadumetorum(bitter yam). Journal of Food Technology 6 (5): 224-226.

57. Oke, O.L. (1966): Chemical studies on the more Temple, V.J., 1998. Lesser known plant foods in commonly used leafy vegetables in Nigeria. Journal of West African Science Association 11: 42-48.

58. Okonkwo, S. I. and Opara,. M. F. (2010): The Analysis of Bambara Nut (Voandzeiasubterranea (L.) thouars) for Sustainability in Africa. Research Journal of Applied Sciences. 5(6): 394-396.

59. Okwu, D. E. and Omodamiro, O.D. (2005): Effects of Hexane Extract and Phytochemical Content of Xylopiaaethaiopila and Ocimumgratisiumon the uterus of guniea pig. Bio-research $3 \mathrm{CIN}$ press

60. Onyenuga, V.A (1968): Nigeria's Food and Feeding stuffs, their Chemistry and Nutritive Value 3rd Edition. Ibadan University Press, Nigeria, p. 99.

61. Oshodi, A.A. (1992): Proximate composition, nutritionally valuable minerals and functional properties of Adenopusbreviflorusbenth seed flour and protein concentrate. Food Chem., 45: 79-83.

62. Osuntogun, B.A, Adewusi, S.R.A, Adewusi,A., Ogundiwin, J.O and Nwasike, C.C (1989): Effect of cultivar, steeping, and malting on tannin, total polyphenol, and cyanide content of Nigerian sorghum. Cereal Chem. 66:87-89.

63. Otegbayo, B. O., Achidi, A. U., Asiedu, R. and Bokanga, M. (2001): Food quality attributes of Ponayams. Proceedings of the Eighth Triennial Symposium of the International Society for Tropical Root Crops, Ibadan, Nigeria. 12-16 November, 2001.

64. Oyenuga, V.A (1959) : Nigeria's Food and Feeding Stuffs. Ibandan, Nigeria. P.99.

65. Princewill-Ogbonna, I.L.andIbeji, C.C. (2015): Comparative study on nutritional and antinutritional composition of three cultivars (red, green and yellow) of aerial yam (Dioscoreabulbifera) Journal of Environmental Science, Toxicology and Food Technology 9: 79-86.

66. Reddy, N.R., Sathe, S.K. and Salumkhe, D.K. (1982): Phytates in legumes and cereals. Advances in Food Research 28: 89-92.

67. Sahoré, D.A.and Amani, N.G. (2005):Composition of wild yams of Côte d'Ivoire. Tropical Science 45 (5): 110113.

68. Sahoré, D.A.and Amani, N.G. (2013): Cooking in the water effect on some wild yam species tuber. International Journal of Educationand Research. 1: 1-14.

69. Sanful, R.E., and Engmann, F.N. (2016):Physico-Chemical and Pasting Characteristics of Flour and Starch from Aerial Yam.American Journal of Food Science and Nutrition, 3(1): 1-7

70. Sanful, R.E. Oduro, I. and Ellis, W.O (2013): Proximate and functional properties of five local varieties of aerial yam (Dioscoreabulbifera) in Ghana. Middle-East Journal of Scientific Research. 14(7): 947 -951.

71. Seelig, M.S. (1993): Interrelationship of magnesium and estrogen in cardiovascular and bone disorders, eclampsia, migraine and premenstrual syndrome. Journal of the American College of Nutrition 12: 442-458.

72. Shanthakumari, S. Mohan, S. and John de Britto, V.R. (2008): Nutritional evaluation and germination of toxic principles in wild yam (Dioscoreaspp). Tropical and Sub-tropical Agrosystems 8,319-325.

73. Shils, M.E., Shike, M., Ross, A.C., Caballero, B.andCousings, R.J. (2006):Modern nutrition in health and disease. 10th Edn., Lippincott Williams and Wilkins, A WoltersKlumer Company, pp 280-281.

74. Singh, U. (1988): Anti-nutritional factors of chickpea and pigeonpea and their removal by processing. Plant Foods for Human Nutrition 38: 251-261.

75. Singh,U. and Singh, B. (1992): Tropical grain legume as important human foods. Economic Botany. 46:310361.

76. Smulders, F.J.M. and Greer, G.G. (1998): Integrating microbial decontamination with organic acids in HACCP programmes for muscle foods: prospects and controversies. International Journal of Food and Microbiology 44: 149-169. 
77. Szentmihalyi, K., Kery,A., Then, M., Lakatos, B., Sandor, Z. and Vinkler, P. (1998): Potassium-sodium ratio for the characterization of medicinal plant extracts with diuretic activity. Phytother. Res., 12: 163-166.

78. Taussky, H.H. and Shorr, E. (1953): A micro colorimetric method of determination of inorganique phosphorus. Journal of Biology and Chemistry 202: 675-875.

79. Tharanathan, R. N. and Mahadevamma, S. (2003): Grain legumes- a boon to human nutrition. Trends Food Sci. Technol., 14: 507-518.

80. Udensi, E.A., Onwuka, G.I. and. Okoli, E.G (2004): Effect of processing on the levels of antinutrtional factors in Muncunautilis. Plant Prod. Res. J., 8: 1-6.

81. Udensi, E.A., Oselebe, H.O. and Iweala, O.O. (2008): The Investigation of Chemical Composition and Functional Properties of Water Yam (Dioscoreaalata): Effect of Varietal Differences. Pakistan Journal of Nutrition 7 (2): 342-344.

82. Udosen, E.O. (1995): Proximate and mineral composition of some Nigerian vegetable.Discov. Innovat., 7(4): 383-386.

83. Ukachukwu, S.N. and Obioha, F.C. (1997): Chemical evaluation of Mucunacochinchinensisas alternative protein feed. Appl. Chem. and Agric. Res., 4: 43-48.

84. Uzogara, S.G., Morton, I.D, and Daniel J.W. (1990): Changes in some anti nutrients of cowpeas (Vignaunguiculta) processed with 'Kanwa' alkaline salt. Plant Foods for HumanNutrition.40:249-25

85. Van Soeest, P.J. (1963): Use of detergent in the analysis of fibrous seeds. A rapid method for the determination of fiber and lignin. J. Ass. Offc. Agr. Chem., 46: 829-835.

86. Vernier ,P., Berthaud, J., Bricas, N. and Marchand J.L (1998) : L'intensification des techniques de culture de l'igname. Acquisetcontraintes. In: L'igname, planteséculaireet culture d'avenir. Actes du séminaire international Cirad-Inra-Orstom-Coraf, 3-6 juin 1997, Montpellier, France. Montpellier, France: CIRAD. pp. 93-101.

87. Wanasundera, J.P.D. and Ravindran, G. (1994): Nutritional assessment of yam (Dioscoreaalata) tubers. Plant Foods for Human Nutrition 46: 33-39.

88. Wheeler, E.L. and Ferrel R.E. (1971): A method for phytic acid determination in wheat and wheat fractions. Cereal Chemistry 48: 312-320.

89. Zannou, A. (2006): Socio-economic, agronomic and molecular analysis of yam and cowpea diversity in the Guinea-Sudan transition zone of Benin. PhD thesis, Wageningen University 